\title{
The 'clean green' delusion
}

\author{
Behind the myths
}

\section{CATH WALLACE}

To look behind the myth of New Zealand's 'clean green' image is to be immediately confronted with a number of difficulties.

There is a lack of coherent collections of readily available data. Further, we New Zealanders like to be smug about ourselves and like both to 'skite' about and to be praised for our qualities. Any challenge to the veracity of the carefully marketed image of New Zealand as 'clean and green' will bring accusations of disloyalty if not of treason to New Zealand.

Claims that New Zealand is clean and green are frequently tossed about - in advertising, in political rhetoric, in a variety of self congratulatory fora. Further, we are advised to do this or that to maintain our clean and green image.

\section{BEING GREEN}

'Greenness' can be taken literally in the sense of colour or figuratively in the sense of environmentally sound. In literal terms, perhaps the bite of the Fair Trading Act can be dodged when we claim to be green. Our long narrow country, lots of rain and temperate climate see to it that in contrast with many other places, New Zealand is literally green. Except in the height of summer this is one of the first impressions to strike the returning wanderer or the dazed arriving tourist. But our greenness is of the green green grass and the drabber green of pine trees. These have displaced the native forests, wetlands and tussocks. In the figurative sense of environmental integrity, our land is much less green than we choose to pretend. Moreover, because humanity's impact is relatively recent, the rate of environmental degradation has been rapid.

\section{BEING CLEAN}

Our claims of being clean are hard to substantiate partly because we do not have much in the way of time series and data to trace this. Certainly, our air is much clearer to look through than that of most of the northern hemisphere. We are lucky, especially in Wellington, that much of our air pollution is swept away. But this paper will argue that we have rested on the security of our low density of people. We have become too smug and must take urgent steps to deal with our polluting and environment degrading habits.

\section{TRACING THE REALITY - SOURCES}

Anyone trying to establish what is the real state of the New Zealand environment and our environmental practices will be confronted with the fact that there is little codification of our data. New Zealand is well behind many of its OECD peers in the development of environmental data series, State of the Environment Reporting, environmental indicators and environmental reporting. While there is some material that is regularly published in compendia, generally it is necessary to turn to scientific, academic and non-governmental sources or to sector organisations and specific government agencies with data that relate to particular sectorial matters. In future, as the monitoring, recording and reporting requirements of the Resource Management Act 1991 (RMA, s35) begin to be observed, data will be available from regional and territorial authorities.

\section{ENVIRONMENT REPORTING AND INDICATORS}

Several of the European countries have State of the Environment Reports or work well under way. Australia has developed its framework for State of the Environment Reporting (Department of the Environment, Sport and Territories, 1994), has State level Reports (eg, Scott \& Christoff, 1991) and a three volume set of reports on the State of the Marine Environment (Zann 1995; Zann \& Kailola 1995; Zann \& Sutton 1995). Even Bangladesh has a State of the Environment Report albeit not one that is official (Anwar, 1993).

New Zealand certainly has some useful data series (eg, Annala 1995a) - but these tend to be ad hoc and scattered, and the reports that present them are at times sanitised. This is especially so when they have been compiled for reporting to international bodies. New Zealand's National Report to the United Nations Conference on Environment and Development (UNCED) in 1991, by the Ministry for the Environment and the Ministry of External Relations and Trade (1992), is one attempt to gather and report on New Zealand's performance but it leaves out much that could be said. The careful crafting of the language is in contrast to the franker, more damning assessment from the academic world (eg, Glasby, 1991).

Decisions at an official level are yet to be taken on which environmental statistics should be collected, how, by whom and at whose expense. Though a number of other OECD countries have advanced considerably 
down the path of tracking the state of their environments, New Zealand's work in this area has languished, primarily for lack of political will and the government's refusal, until recently, to fund or support such work.

There was some academic work done in this area by Jan Wright (1989) and others of the Centre for Resource Management at Lincoln in the 1980s and by the then Department of Statistics (Sheerin, 1991). This work on environmental accounting and other means of re-

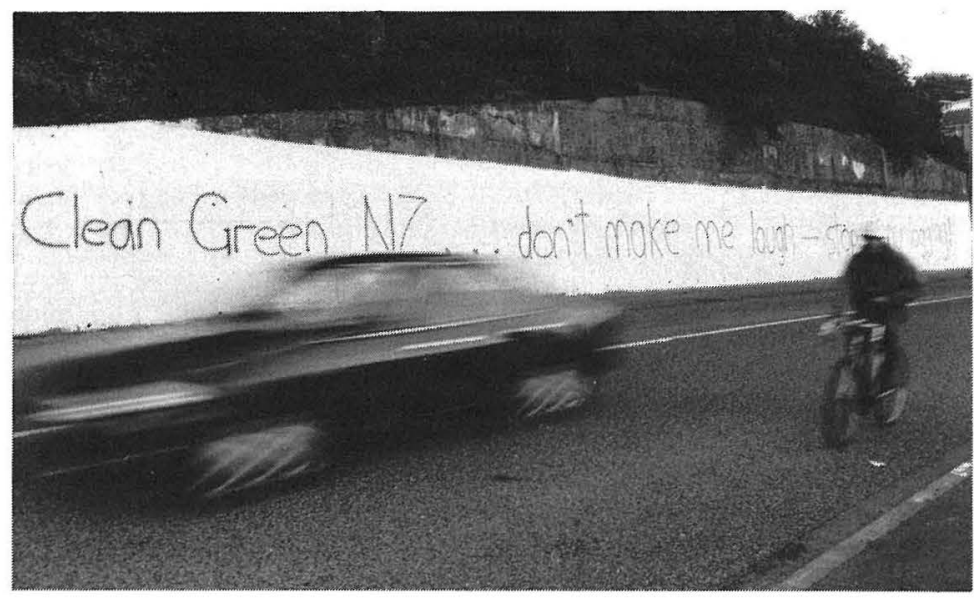
porting environmental change surveyed work done elsewhere, particularly by the OECD (OECD, 1991a, 1991b).

Some of this work was done on commission for the Ministry for the Environment and/or the Department of Statistics in the late 1980s and early 1990s. Eddie Goldberg was the driving force for this work in the Ministry for the Environment (Anon, 1990). He commissioned work by Jonet Ward, and Ruth Beanland which was directed to State of the Environment Reporting, including looking at how the environmental data collection by regional and local government could be sufficiently brought into conformity for use as national data series.

Statistics New Zealand regularly publishes statistics in the New Zealand Official Year Book, some of which relate to the environment - but these are not organised around a clear analytical focus to reflect the health of our environment. For instance the Year Book may report fish catch, export volumes or export value levels but it does not trace the fate of the fish stocks, nor does it track the catch allowed against calculated safely harvestable stock yields.

Statistics New Zealand did try to assemble a range of environmentally relevant data in 1993 and these were published (Statistics New Zealand 1993). While useful, they too have been put together on an ad hoc basis and are not indicators or organised to reveal key environmental questions.

Underfunding of the Ministry for the Environment and that agency's preoccupation with bedding in the Resource Management Act and its other pressing tasks, meant that following the change of government in 1990 until 1995, there was scant progress except for work already in the pipeline. Frustrated by the lack of political commitment to such work, Goldberg left the Minis-

Above: Evans Bay Parade, Wellington, April 1997. Brett Robertson, Victoria University of Weilington.

try in early 1993 to take up a position in the OECD.

One project initiated by Goldberg was the production of a State of the Environment Report. There have been considerable problems with this work. The Ministry now expects this work to see the light of day some time in 1997 with a programme of work over several years.

A further area of work has been the work on environmental indicators. This went into abeyance with the departure of Goldberg but has recently revived. The pressure of an impending visit by an OECD team in June 1995 to review New Zealand's environmental performance may have stimulated renewed efforts. It gained some impetus with the publication in January 1996 of the discussion paper 'National Indicators: building a Framework for a Core Set'. This invited submissions and is part of a process of focus groups and other consultation to discuss methodology, frameworks, to identify suitable indicators and participants. It will be a slow process with indicator development progressing in subject batches over a number of years.

The very slow progress on this work reflects the extreme fiscal squeeze on the Ministry for the Environment. One cynical view current is that the government has not been particularly keen to fund work which might lead to embarrassing discoveries and which might undermine the fictions New Zealand spreads abroad. Recently the government has apparently decided to fund further work in this area, in the 'green package' of the Budget.

\section{THE POLITICS OF CLEAN AND GREEN}

Buhrs and Bartlett (1993) develop the thesis that New Zealand around 1992 had the potential to leap from laggard to world leader. Their idea that New Zealand is a laggard is expressed eloquently:

During much of the 1970s, 1980s and 1990s, environmental policy development in New Zealand, as in many 


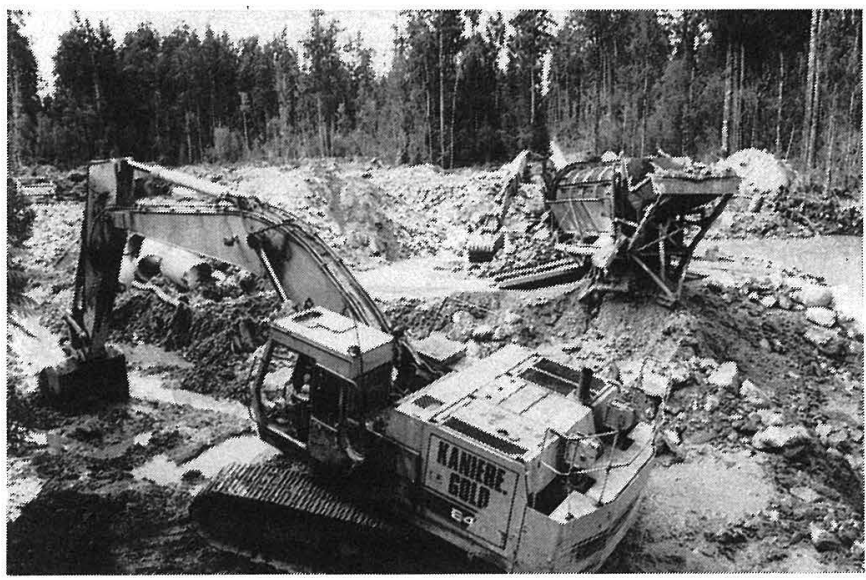

of this agency was transferred to the Ministry of Commerce. (At the time, I was told by someone close to the action that David Caygill, then Minister of Finance, had wanted to dismantle the Ministry of Energy still further. This was prevented when the then Energy Minister David Butcher made his support of Caygill's mini-budget and increase in GST conditional on the Energy Ministry rump being kept as an energy and resources unit within Commerce. I have never been able to verify this story).

Roger Douglas' microeconomic reforms, the removal of land drainage, clearance and various other subsidies, sharply reduced the rate of government-

other countries, has mainly been reactive, pragmatic, fragmented, uneven and slow. ( $p$ 10)

They account for this thus:

A major reason for this can be found in a unique phenomenon at a time when environmental degradation besets most of the world: the 'clean and green syndrome'. During the last two decades, there have been, apart from New Zealand, few if any other western countries where environmental policy has developed on the basis of the notion that environmental problems are still relatively minor. Therefore, it is perhaps the only country where environmental policy has been the result of the politics of clean and green'. (p10)

Buhrs and Bartlett then go on to discuss how this awareness is changing and to speculate whether New Zealand will leap to become world leader.

\section{THE REFORMS OF 1984-90 AND THEIR AFTERMATH}

In fairness, one would probably want to exempt the period from about 1984-1990 from the probably accurate but damning judgement: "reactive, pragmatic, fragmented, uneven, slow". During this period the Labour government was, as in other areas, rather the model of the comprehensive and systematic policy maker. The government came in with an agenda for environmental administration and law change and in dialogue with environmental groups, the Treasury, various business and other interests set about a major process of reform.

The major reforms swept away the old, environmentally damaging 'development' departments: the New Zealand Forest Service, the Department of Lands and Survey, and the Ministry of Works and Services. These were replaced by the Department of Conservation, the Ministry for the Environment, the Parliamentary Commissioner for the Environment, the Department of Lands and Survey Information, and a variety of State Owned Enterprises in forests, land, electricity and works. The Ministry of Energy was not quite extinguished. With the electricity and coal sections carved off into operating units, the rump encouraged damage to the natural environment.

Once the Ministry of Works and Development's planning responsibilities had been transferred to the Ministry for the Environment, that Ministry set about a carefully planned and executed programme of Resource Management Law Reform at the same time that the Department of Conservation was setting up its infrastructure for conservation management.

All of this was far too organised to be dismissed as "reactive, pragmatic, fragmented, uneven and slow." What can however be said is that the shortage of resources in the Ministry for the Environment meant that a great deal was not done that could have been.

Hazardous substances is an issue that languished for years after the 21 Dec 1984 ICI fire put it onto the policy agenda. Always about to be actioned, this area has suffered years of neglect. In a vintage display of 'clean and green' politics, when Michael Szabo reported in New Scientist (31 July 1993) the desk top study that pointed to the potential for there to be over 4,000 contaminated sites in New Zealand, official and primary producer rage was not directed at the fact that such pollution might be the case, but that the matter had been not only publicly reported but reported abroad. It was the damage to the 'clean green' image that mattered, not the reality.

Energy is an issue which had been the focus of attention during the oil price rises in the 1970s and then the focus of concern when the Think Big energy projects were pushed through, despite the opposition to them on both environmental and economic grounds.

Despite the pressure brought to bear in this area, and the singular success of ECO, the Coalition for Open Government, and other groups in opposing the National Development Act, energy policy and the lack of

Above: Kaniere Gold despoiling Ianthe State Forest, 1993. Forest and Bird Protection Society. 
energy efficiency remain of particular concern. This worries not just New Zealand environmentalists but increasingly those following or parties to the Climate Change Convention.

We are embarked on a major rearrangement of our electricity and gas industries but these changes towards market entities are such that energy efficiency and environmental protection will not be encouraged. The institutional and pricing policies seem certain to militate against environmentally sound policies.

Transport policies hardly exist as such. In this area deregulation probably had a negative environmental effect, particularly the switch to trucks rather than rail freight and the deregulation of air transport. The incoherent land transport pricing policies and the huge implicit subsidies to road users may be about to be addressed with the newly released Land Transport Pricing Study, but so far this is just a twinkle in some economists' eyes: the might of the Automobile Association and the resistance of vehicle users to confronting the real costs of our vehicle use has yet to be faced.

Fisheries was left out of the Resource Management Act 1991. Our policies and administration of the marine environment are essentially back where administration of the terrestrial environment was prior to the Resource Management Law Reform. It needs major reform and refocusing with new laws and confirmation of the administration of the marine environment to focus on ecosystem management. The incoherent, inconsistent and fragmented administration of the marine environment requires radical reform.

The conservation estate like other areas of terrestrial native ecosystems, has suffered huge changes. Plant and animal pests, particularly rats and mice, muistelids, possums, goats and deer attack native plants and birdlife. Our loss of species has been considerable. Native forest ecosystems are now in collapse under the assault of pests.

\section{THE PERIOD SINCE 1990}

The Labour government contained a number of Ministers significantly sympathetic to the need to address environmental issues. Geoffrey Palmer as Environment Minister and first Russell Marshall and then Phillip Woollaston as Conservation Minister were active in pushing through environmental reform. The National government has not given priority to environmental issues though a few advances have been made. Some Ministers have been actively hostile and those who would have liked to see more done have easily been sidelined.

The impetus of the departed Labour government has continued however with the passage in 1991 and the bedding in of the Resource Management Act. There have been some gains to the Conservation Estate in terms of additions to it (eg, Kahurangi National Park).

\section{THE RESOURCE MANAGEMENT ACT 1991}

The failure of the government to install two essential elements of the architecture of the Resource Management Act is causing severe difficulties. The first is that except for the mandatory New Zealand Coastal Policy it has so far refused to institute any National Policy Statements or Standards. These are urgently needed in several fields, most urgently of all in the transport, energy, greenhouse gas emission, and related sectors.

Second, the Legal Services Bill was stripped by National of the provisions for assistance for environmental cases under the Resource Management Act. The effect of this is that community and environmental groups, iwi and individuals have been discouraged from defending the environment under the Resource Management Act. They have been deterred by costs awards amounting to tens of thousands and hundred of thousands of dollars.

Companies, particularly mining companies, have used such prospects to dissuade community groups from taking cases to appeal to the Planning Tribunal. In one case, Heritage Gold Co telephoned the members of the local group threatening them with the prospect of loss of personal assets if the case failed. In the case of Peninsula Watchdog v Coeur Gold, the company sought costs from the Watchdog group of over $\$ 400,000$ and were instructed to negotiate this figure with Watchdog. In the original judgement, the Tribunal specifically noted that the case had had merit, although it had failed, that it had been well presented and was not vexatious.

The effect of all this has been to make the Resource Management Act appeal process essentially unavailable to environmental and community interests and individuals.

\section{DOES THE CLEAN GREEN IMAGE MATCH THE REALITY?}

In the absence of well maintained integrated data sets, a survey of how New Zealand lives up to the clean green image cannot be comprehensive. According to figures supplied by the Department of Conservation, New Zealand's flora and fauna has a very high rate of endemism. None of our amphibia or reptiles occur anywhere else; 90 percent of our insects occur here only, and 75 percent of our native birds are endemic. Our environment has suffered the extinction of eight species of flowering plants and 44 species of land birds: At least 407 species of plants and animals are threatened (Department of Conservation 1994).

Formally, over 5 million ha (19 percent) of our land area has some protective designation (13 national parks covering more than two million ha, at least 21 forest parks and nearly 4,000 reserves). Mining and some other quite damaging activity however is not banned from these areas. The possums and other browsers, the rats, mice, ferrets, stoats, goats, deer, feral cats and maraud- 


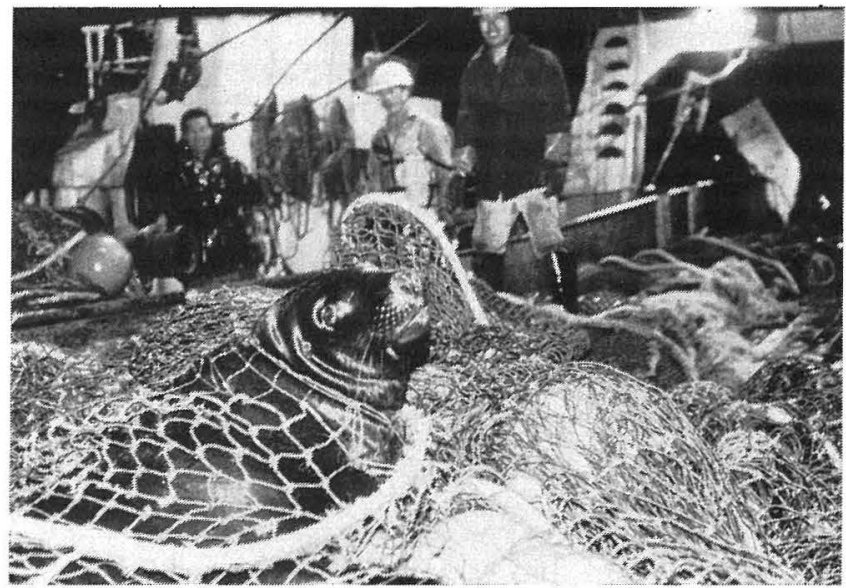

Bight. Hooker's sealions suffered the loss of about 100 for each of 1994 and 1995 (Baird, 1995).

Seabirds, especially albatross, including the mollymawks have suffered very serious population declines over the past few decades. Though there is apparently some environmental change underway which accounts for some of the change, the scientists believe that the long-line fishery in the Southern Ocean may account for a

ing dogs have not noticed that these areas have been designated protected either. Tourists and locals alike flock to these special areas, generating their own environmental pressures as they leave behind their litter, their dogs and hitch hiking vermin.

The result is a massive assault on formally protected and other natural areas. The Department of Conservation's budget has been progressively reduced, while its obligations have expanded so that like the Ministry for the Environment, it has been unable to do what is needed. Protests from ECO and other environmental groups have been brushed aside, year after year, by bland assurances from successive Ministers. These must surely, with their colleagues in Cabinet and the Treasury officials, take much of the blame for the Cave Creek Tragedy which has so belatedly and disastrously turned the spotlight on the crushing inadequacy of these agencies' funding.

\section{MARINE ENVIRONMENT}

There is less than one percent of our total marine area in protection: and the marine reserves legislation is limited in its application to the 12 nautical mile limit. The grounds for reservation are very restrictive, allowing reservation only for scientific study, not for ecosystem protection.

Marine mammals are protected by law as are our native birds, but this has not prevented continuing losses as by-catch in fisheries. From 1983 to 1988 about 200 of the threatened Hector's dolphin (population 3,000 ) were killed in set nets. The mortality has continued since, at the rate of about 10 per year. A total of about 1,000 fur seals, also protected, die in various fisheries (including the West Coast trawl fishery for hoki, the Snares Shelf trawl fishery [squid and barracouta, etc] and the southern blue whiting fishery around the Bounty Islands). 100-200 common dolphins are drowned in the Jack mackerel fishery in the Taranaki significant part of the population losses of some species. Gales' (1993) review of albatrosses considered that at least 12 of the 14 species were adversely affected by long line fishing.

Over 100 fish species are commercially exploited, but the pressure is intense on just a few species which make up most of the value of the catch. Over 90 percent of the commercially caught seafood is exported, earning revenue of about $\$ 1.2$ billion in 1995. About half of this was caught by foreign charter vessels, often with foreign crew (Ministry of Fisheries, 1996:26).

The species which come most under pressure are those which, left to themselves, live to a great age and therefore have very slow population recovery rates but are high value and so subject to heavy fishing pressure, and those which are high value and easy to access. Orange Roughy and the Oreos are long lived and have shown stocks with very serious declines in biomass. These are deep water species and in the case of Roughy may live to $120-130$ years (Annala, 1995:173). Some of these stocks are less than half of the estimated biomass needed to support the maximum sustainable yield, with catches well above those that are sustainable (Annala, 1995:173 \& ff).

Oreos may live even longer - one has been aged at 153 years old (Annala, 1995:204). Estimates presented to the 1996 fisheries stock assessment round show a decline in the stock of smooth oreo in area 3A (west, south Chatham Rise) from over 60,000 t in the early

Above: Hooker's sealion caught in a squid trawler's net off the Auckland Islands, 1997. Mike Donoghue.

Opposite: Damning statistics - the graph depicting the decline of Orange Roughy shows the stock levels well below levels that would support the legal target of the stock for maximum sustainable yield. Don Robertson, National Institute of Water and Atmosphere, 1995. 
1970 s to less than 20,000 t in 1995 . Estimates are based on catch records which themselves have rather large data quality uncertainties attached. The exacf figures are uncertain, but the trend is down. There is some greater uncertainty for the figure for smooth oreo in area 4 , but again, the prognosis is not encouraging (Doonan et al, 1996:13-16).

In contrast, some species such as hoki and squid have been heavily fished but are resilient. Squid is short lived (probably under 18 months) so populations are likely to recover fast and recruitment is driven principally by environmental factors. The sluggish price of hoki and the particular economics of that market have given that species some extra protection. It seemingly is robust with the stock in good shape (Annala, 1995a:123 \& ff).

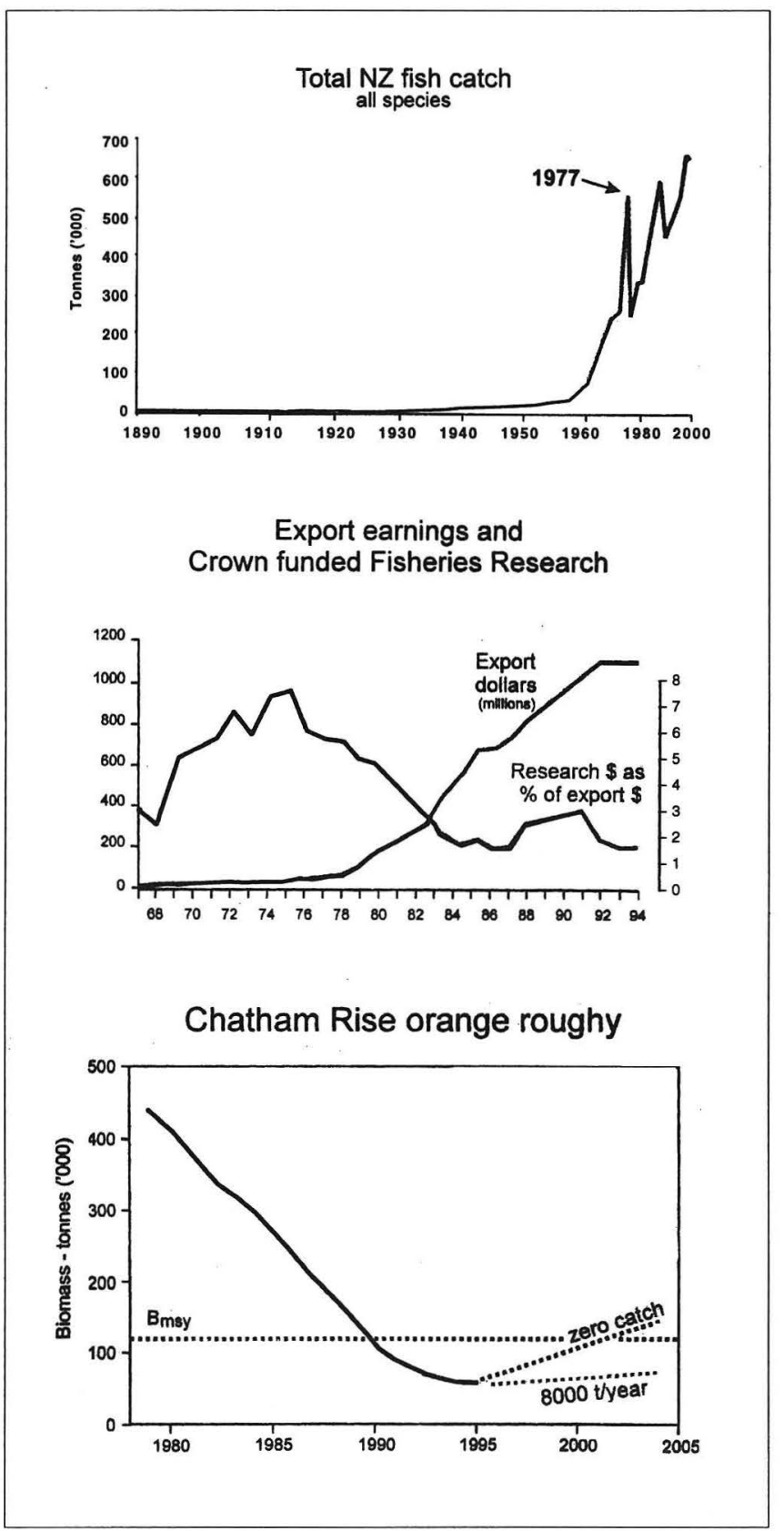

Paua, scallops and rock lobster are also heavily fished. The data is often poor with the scientists in many cases unable to say whether the catch is sustainable or would allow any recovery. The incidental kill of animals, those killed but not taken, can be very high. In the scallop fishery for instance, almost three times the amount of the catch itself is killed by the dredging gear (Morrison, 1995).

The management of the New Zealand fisheries has been progressively converted to the Quota Management System. The focus of this management however has been essentially myopic. The management objective has been to maintain the commercial fisheries without endangering the stocks. There has been little attempt to view the problem in the light of the marine environment as an ecosystem. There are some encouraging signs that the new Ministry of Fisheries may alter this.

The objective of maintaining the fish stocks without undue risk of collapse has in some notable cases not been achieved, primarily because of the intense pressure exerted by the fishing industry, even in the face of considerable uncertainties and data indicating severe stock declines. This pressure is political. When lobbying fails, the industry resorts to legal action to prolong overfishing (eg, the AucklandHauraki Snapper fishery and Orange Roughy).

Ecosystem management of fisheries is notoriously difficult - but New Zealand has made little effort, and suggestions from those interested in the marine environment rather than just the commercial value of the fisheries, that more work on this area be done have been brushed aside until very recently.

The management of the marine environment is seriously fragmented and is probably in violation of Article 192 of the UN Convention of the Law of the Sea 
which places an absolute obligation on states to "preserve and protect" the marine environment. Any exploitation has to be subject to this condition. New Zealand ratified UNCLOS on 25 July 1996, and this came into force on 25 August 1996.

The marine environment is not managed as a whole. It is used as a medium for transport, cables and other communications; and for fishing, recreational, traditional and commercial. It provides vital pollution absorption services but is overloaded with discharges and deposits of pollution. The eroded sediment from our overgrazed pastures smothers the benthic layer of the coastal sea floor for some kilometres out. Persistent organochlorines and other hazardous substances are allowed to contaminate it; plastic and other debris from land and vessels accumulates with detrimental effect on the marine life.

Aquatic algal blooms are apparently increasing; some are toxic. Reasons advanced are various but include serious scientific opinion that climate change and/ or eutrophication could be culprits.

\section{ENERGY AND GREENHOUSE GASES, POLLUTION}

New Zealand's record on energy and greenhouse gas emission is very poor. We have done little since we undertook in 1992 at the Rio Conference (UNCED) to reduce emissions of $\mathrm{CO}_{2}$ to 1990 levels by the year 2000 and New Zealand stands out with Australia as being high in the league of over-emitters. Based on figures from the Secretariat of the UN Framework Convention on Climate Change (FCCC/SB/1996/1), New Zealand is projected by the year 2000 to exceed the 1990 level by 15.7 percent (Australia 15.1 percent). The government has pinned its strategy on using forest growth as an offset for $\mathrm{CO}_{2}$ emissions, ignoring the huge uncertainty margins the scientists had flagged, and insisting on a path that environmentalists warned them was flawed.

Work by Geoff Bertram of Victoria University of Wellington and BERL demonstrates that New Zealand may well actually gain GDP and jobs through diminishing inefficient use of energy if a carbon charge is applied. There would be significant change in the composition of GDP as the economy switched away from energy intensive activity to that which is less so but generates more jobs. The government in other areas has not shied away from major disruption when reforms for the sake of economic efficiency were pursued. The suspicion remains that strong lobby power from a few key industries and an environmentally unsympathetic government is preventing New Zealand from adopting an environmental and economically responsible position.

New Zealand has nothing that could be dignified with the name of a transport policy - except deregulation - yet about 45 percent of our $\mathrm{CO}_{2}$ emissions come from the transport sector.

Methane is the largest of New Zealand greenhouse gas emissions, but since it comes primarily from ruminant burps this is not easy to reduce, without reducing flocks. Potent in its greenhouse effect, methane emissions needs to be reduced by $15-20$ percent compared to the 50-60 percent reduction needed for $\mathrm{CO}_{2}$. In New Zealand methane has declined over five percent this decade due to reductions in sheep and cattle numbers. Nitrous oxide emission levels have been estimated at $19200 t$ per annum, but theere is considerable uncertainty (Working Group on $\mathrm{CO}_{2}$ Policy, 1996).

New Zealand has, with other countries, addressed the problem of ozone emissions. The unwillingness of the New Zealand companies to trade quota allocations for such substances has apparently meant that the expected benefits of the tradeable system put in place amongst users have not been realised, at least according to discussions by quota holders before the Select Committee inquiry into the Ozone Layer Protection Bill in 1996.

The work of regional authorities in controlling air emissions has been greatly hampered by the absence of any national standards for air quality and the lack of any National Policy Statement on the matter. The effect of this has been that New Zealand's air quality management is ad hoc, much less informed than it should be, and riven with uncertainties.

The removal of lead from petrol, a long time coming and beset with problems created by a secretive oil industry, is probably good for the environment long term, but much more could be done to minimise health hazards from aromatics and particulate emissions.

\section{WATER AND LAND USE}

Water quality management standards are incorporated in the Resource Management Act, and that Act should assist long term in the improvement of water management. However as the Parliamentary Commissioner for the Environment recently observed in her report on New Zealand's water classification system, we still do not have clear, consistently applied water quality standards.

Unsustainable land use practices, familiar and routine, are a deep seated problem that New Zealand must address urgently. Those of us brought up on farms have to come to terms with the idea that many of the farming techniques we learnt and which are still being practised, must change if we are to address the degradation of water quality, the poisoning of aquifers, the loss of soil quality and fabric, and the disappearance of native species.

Commercial plantation forestry, beneficial economically and for jobs, helpful too in taking the pressure off old growth forests, has to come to terms with its unsustainable use of pesticides, and management practices that damage water quality.

The removal of kanuka forest for planting pines by Ngati Porou and Korean forestry interests are not in 
keeping with the provisions of the New Zealand Forest Accord. These parties are not signatories to the Accord, but such action will in the long term discredit the reputation of New Zealand-grown timber and will rebound on the industry as a whole. In the same way, the current destruction of some Southland forests and those native forests from the West Coast will bring short term benefits at the expense both of long term reputation and the environment itself.

Environmental groups have accepted the obligation to promote the benefits of plantation forestry properly done, but cannot be expected to ignore the unwillingness of the New Zealand Forest Owners Association and others to commit themselves to strong environmental principles for their activities. This organisation is a signatory to the Accord and its members must surely worry as the marketing advantages of the Accord are eroded by those companies who choose not to comply with the Accord's provisions.

\section{CONCLUSIONS}

This survey is incomplete through limitations of space, time and data. It is enough though, I hope, to convince us that we cannot rely on the 'clean green' mantra to pretend that we do not have deep seated and complex environmental problems. It is a great shame that it has taken the Cave Creek tragedy to focus the minds of politicians and the nation on DoC's problems. It is already clear that the 'green package' Budget will fall well short of the major injection of funds that DoC needs. DoC anyway is just one of the very badly underfunded agencies. The Ministry for the Environment has been able to devote much less than one person to fisheries matters and is hopelessly stretched in every direction.

Fisheries research must be refocused, better financed and kept from capture by the fishing industry. This will require a major change in the bureaucracy.

More broadly in New Zealand, we must admit to the problems, recognise the intrinsic and the non - market value of the environment, accept duties to future generations and to other species. We must resist the extraordinary pressures to regard only financial values as important. Most of all, we must stop our self-delusion.

\section{SOURCES}

Annala J H (comp) (1995a) Report from the Fishery Assessment Plenary, May 1995: stock assessments and yield estimates, 277p Unpublished Report, MAF Fisheries [now Ministry of Fisheries], Wellington.

Annala J H (comp) (1995b) Report from the Special Fishery Assessment Plenary, 29 May 1995: stock assessments and yield estimates for Snapper, 36p Unpublished Report, MAF Fisheries [now Ministry of Fisheries], Wellington.

Anon (1990) State of the Environment Reporting in New Zealand: A Proposal for a Multiagency Project, SER Information Paper No 1, Ministry for the Environment and Department of Statistics, Wellington.

Anwar, Jamal (1993) Bangladesh: The State of the Environment, Coastal Area Resource Development and Management Association, Dhaka.
Baird, SJ (comp) (1995) Report of the MAF Fisheries Assessment Working Group on Non-Fish Species and Fisheries Interactions, MAF Fisheries, Wellington.

Buhrs, Ton \& Robert V Bartlett (1993) Environmental Policy in New Zealand: The Politics of Clean and Green?, Oxford UP, Auckland.

Department of the Environment, Sport and Territories, (1994) State of the Environment Reporting: framework for Australia., DEST, Commonwealth of Australia, Canberra.

Doonan, IJ; McMillan, P J; Coburn R P \& A C Hart (1996) 'Assessment of Chatham Rise Smooth Oreo (OREO 3A and Oreo 4) for 1996', DRAFT, 23 April 1996, NIWA, Wellington.

Glasby, G P (1991) 'A Review of the Concept of Sustainable Management as applied to New Zealand', Journal of the Royal Society of New Zealand, Vol 21(2), June pp61-81.

Gales, R (1993) Co-operative Mechanisms for the Conservation of Albatrosses. Australian Nature Conservation Agency. September 1993. 132pp.

Ministry for the Environment (1996) 'National Indicators: building a Framework for a Core Set', Ministry for the Environment, Wellington.

Ministry for the Environment, Ministry of External Relations and Trade (1992) New Zealand's National Report to the United Nations Conference on Environmental and Development, December 1991: Forging the Links, Wellington.

Ministry of Fisheries (1996) Post-election Brief to the Minister of Fisheries, Wellington. 62pp.

Morrison, M. A (1995) 'An assement if the impact of intensive commercial scallop dredging on undersized scallop populations with application to the assessment of alternative management strategies: A report to the Coramandel Scallop Fisherman's Association' Leigh Marine Lab, Centre for Marine Science, University of Auckland. Mimeo, 34pp.

OECD (1991a) Environmental Indicators: A Preliminary Set, OECD, Paris, 77pp.

OECD (1991b) The State of the Environment OECD, Paris, 297pp.

OECD (1996) Environmental Performance Reviews: New Zealand. OECD, Paris, 201pp.

Scott David and Peter Christoff (1991) 1991 State of the Environment Report: Agriculture and Victoria's Environment, Office of the Commissioner for the Environment, Government of Victoria, Melbourne.

Sheerin, Jeff, et al (1991) Reporting the State of the Environment Information, SER Information Paper No 2, October, Ministry for the Environment and Department of Statistics, Wellington.

Statistics New Zealand 1993) Measuring UP: New Zealanders and the Environment, Statistics New Zealand, Wellington.

Szabo, Michael (1993) 'New Zealand's poisoned paradise,' New Scientist, 31 July 1993.

Working Group on $\mathrm{CO}_{2}$ Policy (1996) Climate Change and $\mathrm{CO}_{2}$ Policy: A Durable Response. Discussion document of the Working Group on $\mathrm{CO}_{2}$ Policy, Ministry for the Environment. 176pp.

Worley Consultants Ltd,(1992) 'Potentially contaminated sites in New Zealand: a broad scale assessment ${ }^{\prime}$, Ministry for the Environment, Wellington, November 1992.

Wright, Janice C (1989) Natural Resource Accounting - A Technique for Improving Planning in New Zealand?, Information Paper 12, Centre for Resource Management, Lincoln College.

Zann, Leon Ped (1995) Our Sea, Our Future-Major Findings of the State of the Marine Environment Report for Australia, Department of the Environment, Sport and Territories, Commonwealth of Australia, Canberra.

Zann, Leon P \& Patricia Kailola, eds (1995) The Marine Environment State of the Marine Environment Report for Australia, Technical Annex 1, Department of the Environment, Sport and Territories, Commonwealth of Australia, Canberra.

Zann, Leon P \& David Sutton, eds (1995) Pollution-State of the Marine Environment Report for Australia, Technical Annex 2, Department of the Environment, Sport and Territories, Commonwealth of Australia, Canberra. 